\title{
Genetics and Hormones in Testicular Descent*
}

\author{
Marko Kaleva and Jorma Toppari
}

Departments of Physiology and Paediatrics, University of Turku, FIN-20520 Turku, Finland

\begin{abstract}
Testicular descent is an essential part of normal male sexual development. Any anomaly that disrupts normal testicular descent will be clinically evident as cryptorchidism. Several factors, such as Hoxa-10, epidermal growth factor (EGF), calcitonin gene-related peptide (CGRP), and hormones, especially androgens and insulin-like factor 3 (INSL-3), have been suggested as being regulators of testicular descent. Testicular descent from the lower pole of the kidney into the extraabdominal scrotal sac is a two-stage process of transabdominal and inguino-scrotal migration. The transabdominal phase is androgen independent, whereas the inguinoscrotal phase depends on androgen action. Disruption of androgen action eg. by environmental anti-androgens are suspected as contributing to cryptorchidism. Estrogens can down-regulate INSL-3 production and thereby disturb testicular descent. Familial occurrence in some cases suggests a possible genetic background for cryptorchidism.
\end{abstract}

Key words: cryptorchidism, testis, INSL-3, androgens, environment, genetics

\section{INTRODUCTION}

Cryptorchidism, the most common congenital malformation in newborn boys, can occur as an isolated anomaly or may be associated with other congenital disorders. Cryptorchidism affects $1-9 \%$ of full term boys at birth and about $1 \%$ at three months of age $^{1}$. Some reports have suggested substantial increase in the prevalence of cryptorchidism over the last few decades $^{2-4}$. In most of the cases the aetiology of cryp-

Address correspondence and requests for reprints to:

Jorma Toppari, M.D., PhD., Department of Physiology,

University of Turku, Kiinamyllynkatu 10, FIN-20520 Turku,

Finland, Tel.: +358-2-3337297, Fax: +358-2-2502610,

E-mail: jorma.toppari@utu.fi

Received 26-06-03, Revised 22-07-03, Accepted 01-09-03 torchidism remains unknown but several risk factors for cryptorchidism have been reported. Low birth weight adjusted to gestational age (small for gestational age) overrules all other risk factors and indicates a possible association with placenta malfunction. Possibly due to unsubstantial symptoms at birth, cryptorchidism is often considered a mild malformation but it is the best characterized risk factor for testicular cancer ${ }^{5,6}$ and a serious risk factor for infertility ${ }^{7,8}$.

\section{TESTICULAR DESCENT}

Development of the male genitalia is a complex series of events including a unique process of testicular descent occurring considerably late in pregnancy. The sexual dimorphic position of the gonads in mam-

* This work was supported by the Turku University Central Hospital, the Academy of Finland and the European Commission (contracts BMH4-CT96-0314, QLK4-CT1999-01422, QLK4-CT2001-00269 and QLK4-CT2002-00603) 
mals is dependent on the differential development of two ligaments during pregnancy: the caudal genitoinguinal ligament, or gubernaculum, and the cranial suspensory ligament (CSL). According to the biphasic model, two independent phases are seen in normal testicular descent. The outgrowth of the gubernaculum and the regression of CSL result in the transabdominal migration of the testes into the inguinal region. The subsequent descent of the testes to the scrotum is due to the shortening of the gubernacular cord and the outgrowth of the gubernacular bulb. The first (transabdominal) phase starts after 10 weeks of gestation when the gubernaculum starts to deposit extracellular matrix rich in glycosaminoglycans and hyaluronic acid and forms a cone-like structure at the caudal end of the gonad. Due to this swelling reaction, the gubernaculum becomes a ligamentous structure which anchors the developing testis close to the inguinal region during fetal growth. In the male fetus the gubernacular swelling is associated with androgen dependent regression of the cranial suspensory ligament (CSL) (Figure 1.) The second (inguinoscrotal) phase of testicular descent starts at around 26 gestational weeks when the gubernaculum begins to bulge through the inguinal canal. The gubernaculum reaches the scrotum by 35 gestational weeks and pulls the testis in its path before the gubernaculum shrinks to a fibrous remnant.

\section{HORMONES}

A normal hypothalamo-pituitary-gonadal axis with normal androgen synthesis and action are commonly accepted as being essential for physiological testicular descent. This is supported by the findings that hypogonadotropic hypogonadism and androgen insensitivity often cause testicular maldescent. Moreover, a high percentage of cryptorchidism resolves spontaneously during the period of high serum gonadotropin and steroid hormone levels at the age of 1-3 months. It has been debated whether this postnatal surge of reproductive hormones has a biological effect since virilization does not occur in infants. Raivio et $\mathrm{al}^{9}$ reported that androgen bioactivity at 3 months of age correlated with serum testosterone concentration and cryptorchid boys had reduced androgen bioactivity. In some studies, decreased serum testoterone levels together with reduced luteinizing hormone (LH) levels have been found ${ }^{10,11}$. The androgen effect is necessary but not sufficient alone for normal testicular descent. The first phase of testicular descent is successful even without androgens. Among androgen insensitivity patients, the testis is located in the inguinal region indicating that only inguinoscrotal descent has failed to occur. Although high androgen levels cause regression of the cranial suspensory ligament, no ovarian descent occurs in congenital adrenal hy-
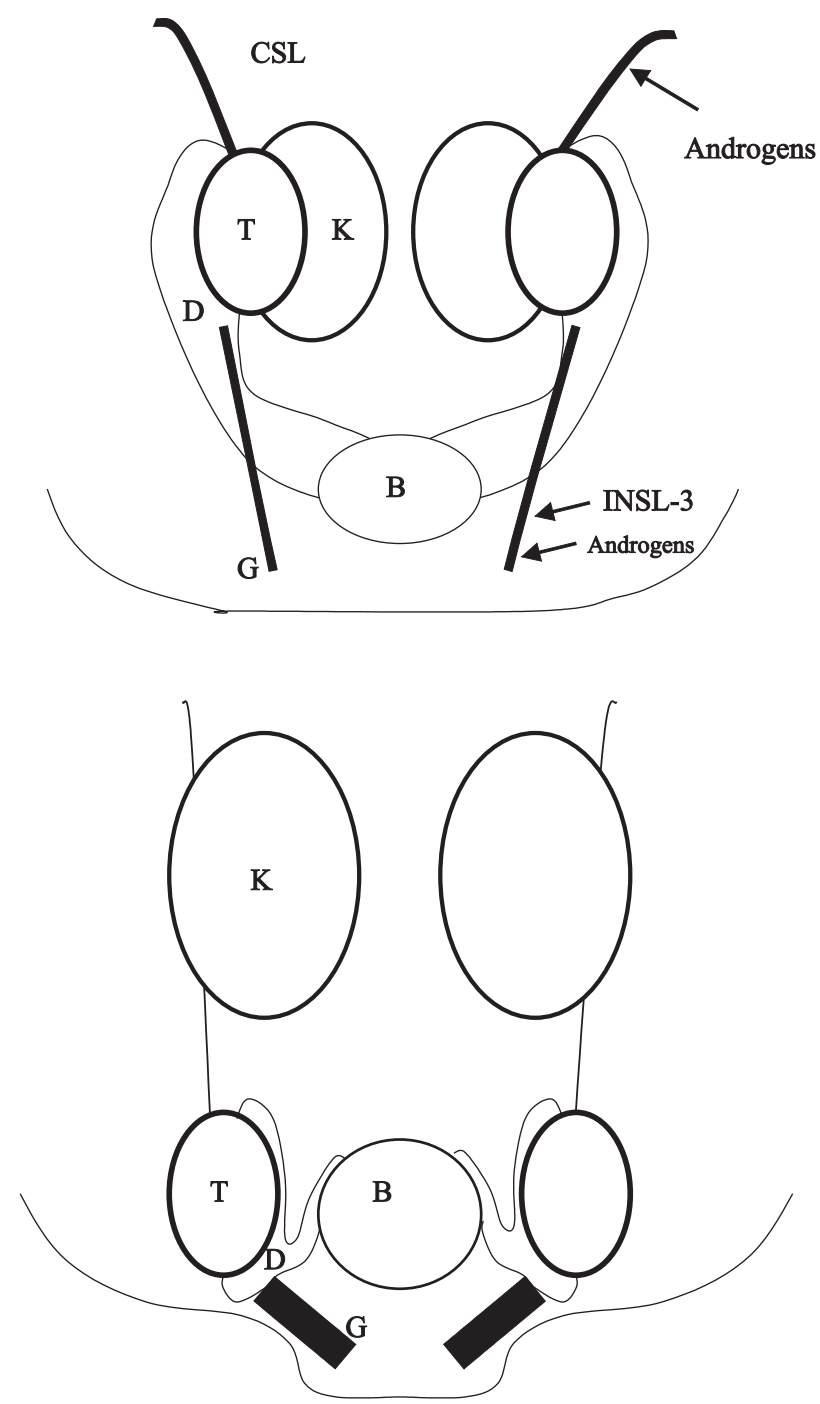

Figure 1. The theory of testicular descent is based on results from both human and experimental animals. At the indifferent stage the gonad is located next to the kidney $(\mathrm{K})$. During the transabdominal phase between week 8 (upper illustration) and week 17 (lower illustration) of testicular descent, the testis (T) is anchored by the swollen gubernaculum $(\mathrm{G})$ close to the inguinal region. Changes in the gubernaculum are regulated by INSL-3 and androgens. Regression of the cranial suspensory ligament (CSL) is androgen dependent. $\mathrm{B}=$ bladder, $\mathrm{D}=$ duct. 
perplasia. The androgen action is mediated by androgen receptor, which contains stretches of polyglutamine. This polyglutamine is encoded by repeats of trinucleotide $\mathrm{CAG}$, and progressive expansion of the CAG repeats in human AR caused a linear decrease of transactivation function ${ }^{12}$. However, CAG repeat length did not show any association with the risk for cryptorchidism.

Androgens might have a direct effect on the cremaster muscle ${ }^{13}$ or the gubernaculum ${ }^{14}$ but indirect mechanisms are also suggested. Hutson and his study group have shown a sex dependent masculinization of the genitofemoral nerve which releases calcitonin gene-related peptide (CGRP) into the gubernaculum and causes rhythmic contractions in rodents ${ }^{15,16}$. Cain et $\mathrm{al}^{17}$ reported that supraphysiologic doses of epidermal growth factor (EGF) can reduce the incidence of antiandrogen-induced (flutamide) cryptorchidism in rats. They also reported that the EGF has no direct effect on Wolffian ducts or the fetal testis. EGF stimulates placental gonadotropin secretion ${ }^{18}$ and it is possible that altered placental function explains the effects of EGF.

The male fetus is exposed to high levels of maternal estrogens during pregnancy and estrogen receptors (ER) are widely expressed in the male reproductive system $^{19}$. In mice, ER $\alpha$ knockout $(\alpha E R K O)$ caused infertility ${ }^{20}$ but $\beta$ ERKO mice were fully fertile ${ }^{21}$. The aromatase knockout mouse (ArKO) has no circulating estrogens due to lack of functional aromatase enzyme. Fertility of initially fully fertile ArKO males decreases with advancing age ${ }^{22,23}$. In humans, only a few cases with ER or aromatase defects have been published and they all had normal male external genitalia with varying semen quality ${ }^{24}$. The role of estrogens in normal testicular descent is obscure. In rats, a single subcutaneous oestrogen injection on day 14 of pregnancy resulted in cryptorchidism in all male offspring ${ }^{25}$. An increased risk of cryptorchidism is associated with nausea during pregnancy, which is believed to be caused by high estrogen levels ${ }^{26}$. Moreover, mothers of cryptorchid boys had higher estradiol levels than control mothers during the first trimester ${ }^{27}$ and Hadziselimovic ${ }^{28}$ reported increased expression of placental estradiol in cryptorchid boys. In the mouse, maternal exposure to estrogens down regulates Insl-3 expression providing a possible mechanism for cryptorchidism $^{29,30}$.
The anti-Müllerian hormone (AMH) is a gonadal hormone secreted by Sertoli cells. AMH was thought to be a regulator of changes in the gubernaculum during testicular descent because lack of AMH often resulted in cryptorchidism in the inguinal region. However, Bartlett et $\mathrm{al}^{31}$ showed that testicular descent was normal in AMH receptor-deficient mice. Thus, it seems that AMH is responsible in male fetuses for regression of the Müllerian ducts but changes in the gubernaculum are regulated by other factors. Hence, maldescent of the testes in humans with lack of AMH might be the result of an anatomical connection of the gonads to the persistent Müllerian ducts.

\section{ENVIRONMENTAL FACTORS}

On the grounds of increased incidence of cryptorchidism in springtime ${ }^{32-34}$, environmental factors have been suggested as affecting testicular descent. Probably this seasonal variation is associated with the circannual rhythm of hormonal action. In normal men, an increased secretion of luteinising hormone (LH), follicle stimulating hormone (FSH), testosterone and inhibin has been found in May-June, with a nadir in August ${ }^{35,36}$. A cyclical pattern might be induced by light or some other factors.

A theory of testicular dysgenesis syndrome (TDS) was presented by Skakkebaek ${ }^{37}$. According to the TDS theory, adverse changes in male reproductive health share the same risk factors. There is evidence that not only cryptorchidism and hypospadias but also testicular cancer and male infertility have a fetal origin. Low birth weight has been associated with testicular cancer, cryptorchidism, hypospadias and low sperm counts $^{38,39}$. The increased risk of testicular cancer in cryptorhid patients remains regardless of treatment, and is also increased in contralateral testes of unilateral cases ${ }^{5,40}$. Testicular cancer patients have a reduced fertility already prior to the cancer diagnosis ${ }^{41}$. Both genetic and environmental factors, including endocrine disrupting chemicals, can contribute to the development of $\operatorname{TDS}^{42}$. This possibility is supported by findings showing that exogenous oestrogens and antiandrogens cause disorders of genital development in animals $^{43-45}$.

\section{GENES}

A heritable background of cryptorchidism has been 
suggested due to familial occurrence. Moreover, genetic syndromes might result in cryptorchidism and an increased probability for coexistence with other genital disorders has been reported. Weidner et $\mathrm{al}^{46}$ screened risk factors for cryptorchidism and they reported that cryptorchidism was associated with hypospadias 3 times more often than expected, and an almost 4-fold increased risk of cryptorchidism was observed when an older brother had been cryptorchid as well.

Microdeletions of $\mathrm{Y}$ chromosome long arm (Yq) often result in improper spermatogenesis causing oligo- or azoospermia ${ }^{47,48}$. Microdeletions as a cause of cryptorchidism has also been investigated, and Foresta et $\mathrm{al}^{49}$ reported microdeletions in the AZF region of $\mathrm{Yq}$ in $27.5 \%$ of cryptorchid males. This remains to be confirmed in other populations.

INSL-3, also known as relaxin-like factor (RLF), is a product of Leydig cells and is probably needed for normal testicular descent. Male mice mutant for INSL3 were cryptorchid and showed improper development of the gubernaculum ${ }^{50,51}$, whereas in female mice the overexpression of INSL-3 caused ovary descent ${ }^{52}$. The effect of INSL- 3 can be augmented by AMH and dihydrotestosterone ${ }^{53}$. Thus, INSL-3 is an apparent regulator of testicular descent in rodents. The receptor for INSL-3 has been recently identified and named LGR-8 (leucine-rich repeat-containing $\mathrm{G}$ protein-coupled receptor 8) or Great (G protein-coupled receptor affecting testis descent $)^{54,55}$. The correspondence between INSL-3 as ligand and LGR8/Great as receptor was suggested by the phenotype similarity between the Great mutant mice and the Insl3 knockout mu$\operatorname{tants}^{51,56}$. In humans several polymorphisms in the INSL-3 gene have been identified but mutations are rarely associated with cryptorchidism ${ }^{57-60}$. Likewise, Gorlov $^{61}$ reported nucleotide variations in LGR-8 cDNA but unique heterozygous mutation was identified only in one patient. In our own material we found only polymorphisms in LGR-8 gene ${ }^{62}$. In contrast, in a recent cohort of 87 ex-cryptorchid patients, Ferlin et $\mathrm{al}^{63}$ found three heterozygous mutations in the INSL3 gene in four patients and one heterozygous LGR8/Great mutation in four patients $(9.2 \%)$. The eight patients showed different phenotypes, ranging from bilateral cryptorchidism to retractile testes while the endocrine function of the testis was normal in all subjects suggesting that alterations of the INSL3-
LGR8/Great system could be responsible, at least in part, for failure of the testicular descent. Thus far, there is no biological explanation as to how the heterozygous mutations could affect humans differently from mice that are normal when only one allele of the INSL-3 or LGR8 genes is missing ${ }^{56}$.

Homeobox (HOX) genes seem to play a key role in the morphogenesis of the urogenital mesenchyma. Homozygous male mice mutated for Hoxa-10 gene exhibited cryptorchidism and gubernacular abnormalities and they also manifested defects in spermatogenesis $^{64}$. Polymorphisms in exon 1 of Hoxa- 10 gene have been found but no causative mutations have been identified until now in humans ${ }^{65}$.

\section{CONCLUSION}

Cryptorchidism is a common condition in newborn boys inducing fertility problems later in life if an appropriate treatment is not applied. Several risk factors for cryptorchidism have been described indicating multifactorial background. New candidate genes, like INSL-3 and Hoxa-10, have also been investigated but thus far, cryptorchidism has most often been associated with mutations of genes of androgen receptor or steroidogenic enzymes that are needed for androgen production or gene mutations leading to hypogonadotropic hypogonadism.

\section{Acknowledgements}

This work was supported by the Turku University Central Hospital, the Academy of Finland and the European Commission (contracts BMH4-CT96-0314, QLK4-CT1999-01422, QLK4-CT2001-00269 and QLK4-CT2002-00603).

\section{REFERENCES}

1. Toppari J, Kaleva M, 1999 Maldescendus testis. Horm Res 51: 261-269.

2. Group JRHCS, 1986 Cryptorchidism: an apparent substantial increase since 1960. John Radcliffe Hospital Cryptorchidism Study Group. Br Med J 293: 1401-1404.

3. Group JRHCS, 1992 Cryptorchidism: a prospective study of 7500 consecutive male births, 1984-8. John Radcliffe Hospital Cryptorchidism Study Group. Arch Dis Child 67: 892-899.

4. Chilvers C, Pike MC, Forman D, Fogelman K, Wadsworth ME, 1984 Apparent doubling of frequency of undescended testis in England and Wales in 1962-81. Lancet 2: 330332 . 
5. Moller H, Prener A, Skakkebaek NE, 1996 Testicular cancer, cryptorchidism, inguinal hernia, testicular atrophy, and genital malformations: case-control studies in Denmark. Cancer Causes Control 7: 264-274.

6. Prener A, Engholm G, Jensen OM, 1996 Genital anomalies and risk for testicular cancer in Danish men. Epidemiology 7: 14-19.

7. Chilvers C, Dudley NE, Gough MH, Jackson MB, Pike MC, 1986 Undescended testis: the effect of treatment on subsequent risk of subfertility and malignancy. J Pediatr Surg 21: 691-696.

8. Cortes D, Thorup JM, Visfeldt J, 2001 Cryptorchidism: aspects of fertility and neoplasms. A study including data of 1,335 consecutive boys who underwent testicular biopsy simultaneously with surgery for cryptorchidism. Horm Res 55: 21-27.

9. Raivio T, Toppari J, Kaleva M, et al, 2003 Serum androgen bioactivity in cryptorchid and noncryptorchid boys during postnatal reproductive hormone surge. J Clin Endocrinol Metab 88: 2597-2599.

10. Job JC, Toublanc JE, Chaussain JL, Gendrel D, Garnier P, Roger M, 1988 Endocrine and immunological findings in cryptorchid infants. Horm Res 30: 167-172.

11. Bollerslev J, Rohl H, Krag Sorensen E, Bennet P, 1986 Gonadotropin and androgen levels in patients operated upon for cryptorchidism. Dan Med Bull 33: 336-338.

12. Chamberlain NL, Driver ED, Miesfeld RL, 1994 The length and location of CAG trinucleotide repeats in the androgen receptor $\mathrm{N}$-terminal domain affect transactivation function. Nucleic Acids Res 22: 3181-3186.

13. Johansen TE, Klein H, 1993 Evidence of androgen receptivity in the pathway of testicular descent in humans. A postnatal study. Eur Urol 23: 466-468.

14. Hosie S, Wessel L, Waag KL, 1999 Could testicular descent in humans be promoted by direct androgen stimulation of the gubernaculum testis? Eur J Pediatr Surg 9: 37-41.

15. Park WH, Hutson JM, 1991 The gubernaculum shows rhythmic contractility and active movement during testicular descent. J Pediatr Surg 26: 615-617.

16. Terada M, Goh DW, Farmer PJ, Hutson JM, 1994 Calcitonin gene-related peptide receptors in the gubernaculum of normal rat and 2 models of cryptorchidism. J Urol 152: 759-762.

17. Cain MP, Kramer SA, Tindall DJ, Husmann DA, 1994 Epidermal growth factor reverses antiandrogen induced cryptorchidism and epididymal development. J Urol 152: 770-775.

18. Morrish DW, Bhardwaj D, Dabbagh LK, Marusyk H, Siy O, 1987 Epidermal growth factor induces differentiation and secretion of human chorionic gonadotropin and placental lactogen in normal human placenta. J Clin Endocrinol Metab 65: 1282-1290.

19. Saunders PT, Sharpe RM, Williams K, et al, 2001 Differential expression of oestrogen receptor alpha and beta proteins in the testes and male reproductive system of human and non-human primates. Mol Hum Reprod 7: 227-236.
20. Couse JF, Korach KS, 1999 Estrogen receptor null mice: what have we learned and where will they lead us? Endocr Rev 20: 358-417.

21. Krege JH, Hodgin JB, Couse JF, et al, 1998 Generation and reproductive phenotypes of mice lacking estrogen receptor beta. Proc Natl Acad Sci U S A 95: 15677-15682.

22. Fisher CR, Graves KH, Parlow AF, Simpson ER, 1998 Characterization of mice deficient in aromatase (ArKO) because of targeted disruption of the cyp19 gene. Proc Natl Acad Sci U S A 95: 6965-6970.

23. Robertson KM, Simpson ER, Lacham-Kaplan O, Jones ME, 2001 Characterization of the fertility of male aromatase knockout mice. J Androl 22: 825-830.

24. Rochira V, Balestrieri A, Madeo B, et al, 2001 Congenital estrogen deficiency: in search of the estrogen role in human male reproduction. Mol Cell Endocrinol 178: 107-115.

25. Grocock CA, Charlton HM, Pike MC, 1988 Role of the fetal pituitary in cryptorchidism induced by exogenous maternal oestrogen during pregnancy in mice. J Reprod Fertil 83: 295-300.

26. Henderson BE, Benton B, Jing J, Yu MC, Pike MC, 1979 Risk factors for cancer of the testis in young men. Int $\mathbf{J}$ Cancer 23: 598-602.

27. Bernstein L, Pike MC, Depue RH, Ross RK, Moore JW, Henderson BE, 1988 Maternal hormone levels in early gestation of cryptorchid males: a case- control study. Br J Cancer 58: 379-381.

28. Hadziselimovic F, Geneto R, Emmons LR, 2000 Elevated placental estradiol: a possible etiological factor of human cryptorchidism. J Urol 164: 1694-1695.

29. Emmen JM, McLuskey A, Adham IM, et al, 2000 Involvement of insulin-like factor 3 (Insl3) in diethylstilbestrolinduced cryptorchidism. Endocrinology 141: 846-849.

30. Nef S, Shipman T, Parada LF, 2000 A molecular basis for estrogen-induced cryptorchidism. Dev Biol 224: 354-361.

31. Bartlett JE, Lee SM, Mishina Y, et al, 2002 Gubernacular development in Mullerian inhibiting substance receptor- deficient mice. BJU Int 89: 113-118.

32. Hjertkvist M, Damber JE, Bergh A, 1989 Cryptorchidism: a registry based study in Sweden on some factors of possible aetiological importance. J Epidemiol Community Health 43: 324-329.

33. Czeizel A, Erodi E, Toth J, 1981 An epidemiological study on undescended testis. J Urol 126: 524-527.

34. Jackson MB, Swerdlow AJ, 1986 Seasonal variations in cryptorchidism. J Epidemiol Community Health 40: 210213.

35. Meriggiola MC, Noonan EA, Paulsen CA, Bremner WJ, 1996 Annual patterns of luteinizing hormone, follicle stimulating hormone, testosterone and inhibin in normal men. Hum Reprod 11: 248-252.

36. Martikainen H, Tapanainen J, Vakkuri O, Leppaluoto J, Huhtaniemi I, 1985 Circannual concentrations of melatonin, gonadotrophins, prolactin and gonadal steroids in males in a geographical area with a large annual variation in daylight. Acta Endocrinol 109: 446-450.

37. Skakkebaek NE, Rajpert-De Meyts E, Main KM, 2001 Testicular dysgenesis syndrome: an increasingly common 
developmental disorder with environmental aspects. Hum Reprod 16: 972-978.

38. Moller H, Skakkebaek NE, 1997 Testicular cancer and cryptorchidism in relation to prenatal factors: case-control studies in Denmark. Cancer Causes Control 8: 904-912.

39. Francois I, de Zegher F, Spiessens C, D'Hooghe T, Vanderschueren D, 1997 Low birth weight and subsequent male subfertility. Pediatr Res 42: 899-901.

40. Berthelsen JG, Skakkebaek NE, 1983 Gonadal function in men with testis cancer. Fertil Steril 39: 68-75.

41. Jacobsen R, Bostofte E, Engholm G, Hansen J, Skakkebaek NE, Moller H, 2000 Fertility and offspring sex ratio of men who develop testicular cancer: a record linkage study. Hum Reprod 15: 1958-1961.

42. Norgil Damgaard I, Main KM, Toppari J, Skakkebaek NE, 2002 Impact of exposure to endocrine disrupters in utero and in childhood on adult reproduction. Best Pract Res Clin Endocrinol Metab 16: 289-309.

43. McIntyre BS, Barlow NJ, Foster PM, 2001 Androgenmediated development in male rat offspring exposed to flutamide in utero: permanence and correlation of early postnatal changes in anogenital distance and nipple retention with malformations in androgen-dependent tissues. Toxicol Sci 62: 236-249.

44. McLachlan JA, 1979 Transplacental effects of diethylstilbestrol in mice. Natl Cancer Inst Monogr 51: 67-72.

45. Fisher JS, Macpherson S, Marchetti N, Sharpe RM, 2003 Human 'testicular dysgenesis syndrome': a possible model using in-utero exposure of the rat to dibutyl phthalate. Hum Reprod 18: 1383-1394.

46. Weidner IS, Moller H, Jensen TK, Skakkebaek NE, 1999 Risk factors for cryptorchidism and hypospadias. J Urol 161: 1606-1609.

47. Reijo R, Alagappan RK, Patrizio P, Page DC, 1996 Severe oligozoospermia resulting from deletions of azoospermia factor gene on Y chromosome. Lancet 347: 1290-1293.

48. Vogt PH, Edelmann A, Kirsch S, et al, 1996 Human Y chromosome azoospermia factors (AZF) mapped to different subregions in Yq11. Hum Mol Genet 5: 933-943.

49. Foresta C, Moro E, Garolla A, Onisto M, Ferlin A, 1999 $\mathrm{Y}$ chromosome microdeletions in cryptorchidism and idiopathic infertility. J Clin Endocrinol Metab 84: 3660-3665.

50. Nef S, Parada LF, 1999 Cryptorchidism in mice mutant for Insl3. Nat Genet 22: 295-299.

51. Zimmermann S, Steding G, Emmen JM, et al, 1999 Targeted disruption of the Insl3 gene causes bilateral cryptorchidism. Mol Endocrinol 13: 681-691.

52. Adham IM, Steding G, Thamm T, et al, 2002 The overex- pression of the insl3 in female mice causes descent of the ovaries. Mol Endocrinol 16: 244-252.

53. Kubota Y, Temelcos C, Bathgate RA, et al, 2002 The role of insulin 3, testosterone, Mullerian inhibiting substance and relaxin in rat gubernacular growth. Mol Hum Reprod 8: 900-905.

54. Hsu SY, Nakabayashi K, Nishi S, et al, 2002 Activation of orphan receptors by the hormone relaxin. Science 295 : 671-674.

55. Kumagai J, Hsu SY, Matsumi H, et al, 2002 INSL3/Leydig insulin-like peptide activates the LGR8 receptor important in testis descent. J Biol Chem 277: 31283-31286.

56. Overbeek PA, Gorlov IP, Sutherland RW, et al, 2001 A transgenic insertion causing cryptorchidism in mice. Genesis 30: 26-35.

57. Tomboc M, Lee PA, Mitwally MF, Schneck FX, Bellinger M, Witchel SF, 2000 Insulin-like 3/relaxin-like factor gene mutations are associated with cryptorchidism. J Clin Endocrinol Metab 85: 4013-4018.

58. Koskimies P, Virtanen H, Lindstrom M, et al, 2000 A common polymorphism in the human relaxin-like factor (RLF) gene: no relationship with cryptorchidism. Pediatr Res 47: 538-541.

59. Krausz C, Quintana-Murci L, Fellus M, Siffroi JP, McElreavey K, 2000 Absence of mutations involving the INSL3 gene in human idiopathic cryptorchidism. Mol Hum Reprod 6: 298-302.

60. Lim HN, Rajpert-de Meyts E, Skakkebaek NE, Hawkins JR, Hughes IA, 2001 Genetic analysis of the INSL3 gene in patients with maldescent of the testis. Eur J Endocrinol 144: 129-137.

61. Gorlov IP, Kamat A, Bogatcheva NV, et al, 2002 Mutations of the GREAT gene cause cryptorchidism. Hum Mol Genet 11: 2309-2318.

62. Roh J, Virtanen H, Kumagai J, et al, In Press Lack of LGR8 gene mutation in Finnish patients with a family history of cryptorchidism. Reproductive BioMedicine Online. (In Press).

63. Ferlin A, Simonato M, Bartoloni L, et al, 2003 The INSL3LGR8/GREAT Ligand-Receptor Pair in Human Cryptorchidism. J Clin Endocrinol Metab 88: 4273-4279.

64. Rijli FM, Matyas R, Pellegrini M, et al, 1995 Cryptorchidism and homeotic transformations of spinal nerves and vertebrae in Hoxa-10 mutant mice. Proc Natl Acad Sci USA 92: 8185-8189.

65. Kolon TF, Wiener JS, Lewitton M, Roth DR, Gonzales ET, Jr.Lamb DJ, 1999 Analysis of homeobox gene HOXA10 mutations in cryptorchidism. J Urol 161: 275280. 